\title{
Effectiveness of different vaccine formulations against vibriosis caused by Vibrio vulnificus serovar E (biotype 2) in European eels Anguilla anguilla
}

\author{
Rosa Collado, Belén Fouz, Eva Sanjuán, Carmen Amaro* \\ Departamento de Microbiología y Ecología, Facultad de Biología, Universidad de Valencia, Burjassot 46100, Spain
}

\begin{abstract}
Vibriosis due to Vibrio vulnificus serovar E (biotype 2) is one of the main causes of mortality in European eels cultured in Europe. The main objective of this study was to develop a vaccine and a vaccination procedure against this pathogen. With this aim, we tested several vaccine formulations (inactivated whole-cells with and without toxoids - inactivated extracellular products - from capsulated and uncapsulated strains, attenuated live vaccines and purified lipopolysaccharide [LPS]) on eels maintained under controlled laboratory conditions using different delivery routes (injection and immersion). To study the immune response we estimated antibody titers and bactericidal/bacteriostatic activity in mucus and serum. To evaluate protection, we calculated the relative percent survival (RPS) after intraperitoneal (i.p.) injection and bath challenge of the pathogen. The overall results indicate that: (1) capsular antigens seem to be essential for protective immunization; (2) vaccines confer the highest protection when administered by i.p. injection; (3) booster is needed to achieve good protection by immersion; (4) enriching the vaccine with toxoids enhances protection to optimal levels (RPS values around 70 to $100 \%$, depending on the delivery route); and (5) the protective effect in serum and mucus depends on the route of administration and seems to be related to the production of specific antibodies.
\end{abstract}

KEY WORDS: Vibrio vulnificus serovar E · Vibrio vulnificus biotype $2 \cdot$ Eel vaccines · Vibrio vaccines . Vaccination by injection $\cdot$ Vaccination by prolonged immersion

\section{INTRODUCTION}

Vibriosis caused by the pathogenic bacterium Vibrio vulnificus serovar E (formerly biotype 2) (Biosca et al. 1997a) is the main cause of mortality in eels Anguilla anguilla cultured in intensive systems in several European countries, occasioning important economic losses (Austin \& Austin 1993, Biosca 1994, Нøi 1999). The pathogen, initially classified as Vibrio sp. (Muroga et al. 1976a,b) and later as $V$. vulnificus biotype 2 by Tison et al. (1982), constitutes a lipopolysaccharide (LPS)-based homogeneous O serogroup within the species (Biosca et al. 1996), named serovar E (Biosca et al. 1997a). This

*Corresponding author. E-mail: carmen.amaro@uv.es vibriosis was detected for the first time in cultured eels in Spain in the late 1980s (Biosca et al. 1991), and despite the reduction of water salinity, recurrent epizootic outbreaks occurred (Biosca 1994). The pathogen was also isolated from diseased eels in the North of Europe in the second half of the 1990s (Biosca et al. 1997a, Dalsgaard et al. 1998, Høi 1999). In this geographical area, $V$. vulnificus also caused disease in both freshand brackish-water eel farms (Høi 1999).

The efficacy of intensive medication to control this vibriosis seems to be limited, as recurrent outbreaks were registered and resistant strains were isolated after antibiotic treatments (Amaro et al. 1992b, Нøi 1999). Moreover, the environmental effects of this practice constitute a serious risk to human health, since 
Vibrio vulnificus serovar E is an opportunistic human pathogen (Amaro \& Biosca 1996) which is able to survive and spread infection through water (Amaro et al. 1995).

To make eel culture profitable, in both brackish and fresh water, alternative strategies are needed to solve the problem, and should focus mainly on preventative measures. The use of vaccines in aquaculture has been shown to successfully protect fish against bacterial diseases, such as vibriosis (caused by Listonella anguillarum [formerly Vibrio anguillarum] and V. ordalii), edwardsiellosis, furunculosis, streptococcosis and pasteurellosis (Song et al. 1982, Austin 1983, Larsen 1988, Smith 1988, Dec et al. 1990, Roogers \& Xu 1992, Magariños et al. 1994, Quentel \& Ogier de Baulny 1995, Toranzo et al. 1995, Romalde et al. 1996, Gravningen et al. 1998). In particular, the success achieved in immunization against other vibrioses (Smith 1988) suggests that the best solution would be an effective vaccine against $V$. vulnificus. Although numerous vaccines against other vibrioses have been developed and licensed to date, no vaccine against $V$. vulnificus serovar $\mathrm{E}$ is available at present. The main objective of this study was to develop a vaccine and a vaccination procedure against this pathogen. With this aim, we tested several vaccine formulations on eels maintained under controlled laboratory conditions using different delivery routes (injection and immersion). From our previous results we knew that capsule, LPS and toxins of $V$. vulnificus serovar $\mathrm{E}$ are essential for eel virulence, and that this bacterium is an extracellular pathogen which can survive and multiply in blood (Biosca et al. 1993b, Amaro at al. 1994, Biosca \& Amaro 1996, Amaro et al. 1997). Thus, we chose 2 strains, capsulated and uncapsulated, and prepared (1) bacterins inactivated by formalin or formalin and heating and supplemented or not with toxoids, (2) an attenuated live vaccine, and (3) an LPS-based vaccine. Since in higher vertebrates the main protective immune response against extracellular bacteria is the humoral one (Gotschlich 1993), we tested this response by measuring the antibody titers and studying the bactericidal/bacteriostatic effect of serum and skin mucus. The efficacy of the vaccines was assayed by calculating the relative percent survival (RPS) after intraperitoneal (i.p.) and bath challenges with the homologous pathogen. Finally, we performed dot blot assays with serum samples of vaccinated eels to identify which antigens induce protective immunity.

\section{MATERIALS AND METHODS}

Bacterial strains. The selected Vibrio vulnificus strains and their characteristics are shown in Table 1. The strain NCIMB 2137 was originally isolated from Japanese eel Anguilla japonica and was received as a pure culture of translucent colonies. This strain seems to be constitutively translucent since it does not revert to the opaque morphology (Biosca et al. 1993b). The strain E86 (Spanish Collection of Type Cultures, CECT, 4604) was originally isolated from European eel as a pure culture of opaque colonies (o). The translucent variant (t) of this strain was obtained in the laboratory by using the methodology described by Biosca et al. (1993a). Strains E109 (CECT 4606), of V. vulnificus biotype 1, and HB-101, of Escherichia coli, were used in dot blot assays. Strain CECT 4606 was originally isolated from the surface of healthy European eel. All strains were routinely cultured in Tryptic Soy Agar (Oxoid) supplemented with $0.5 \% \mathrm{Na} \mathrm{Cl}$ (TSA-1) for $24 \mathrm{~h}$ at $25^{\circ} \mathrm{C}$. Frozen stocks were maintained at $-80^{\circ} \mathrm{C}$ in marine broth 2216 (Difco Laboratories) containing 15\% (v/v) glycerol.

Vaccine preparation. The different vaccine formulations are listed in Table 2. To prepare whole-cell bacterins (WCB), opaque (WCBo) and translucent (WCBt) cells of strain CECT 4604 were recovered from TSA-1 plates with sterile phosphate-buffered saline $(\mathrm{pH} 7)$ containing $1 \% \mathrm{NaCl}(\mathrm{wt} / \mathrm{v})$ (PBS-1) after incubation for $24 \mathrm{~h}$ at $25^{\circ} \mathrm{C}$. Then, cells were inactivated by adding $1 \%(\mathrm{v} / \mathrm{v})$ formalin without (WCBF) or with subsequent

Table 1. Origin, colony type and degree of virulence for eel of Vibrio vulnificus strains used in this study. i.p.: intraperitoneal injection; o: opaque; t: translucent

\begin{tabular}{|c|c|c|c|c|c|}
\hline \multirow[t]{2}{*}{ Strain } & \multirow[t]{2}{*}{ Serovar } & \multirow{2}{*}{$\begin{array}{l}\text { Colony } \\
\text { type }\end{array}$} & \multirow[t]{2}{*}{ Origin } & \multicolumn{2}{|c|}{$\mathrm{LD}_{50}$ for eel ${ }^{\mathrm{a}}$} \\
\hline & & & & i.p. & Immersion \\
\hline CECT $4604(\mathrm{o})^{\mathrm{b}}$ & $\mathrm{E}$ & o & Diseased European eel & $1.6 \times 10^{1}$ & $8.0 \times 10^{5}$ \\
\hline CECT $4604(\mathrm{t})^{\mathrm{b}}$ & E & $\mathrm{t}$ & Diseased European eel & $9.2 \times 10^{3}$ & $>10^{8}$ \\
\hline NCIMB 2137 & E & $\mathrm{t}$ & Diseased Japanese eel & $7.3 \times 10^{3}$ & $>10^{8}$ \\
\hline CECT 4606 & Non-E & $\mathrm{o}$ & Healthy European eel & $>10^{8}$ & $>10^{8}$ \\
\hline \multicolumn{6}{|c|}{$\begin{array}{l}{ }^{\text {a }} \text { Degree of virulence is expressed as mean lethal dose }\left(\mathrm{LD}_{50}\right) \text { in colony forming units (cfu) fish }{ }^{-1}(\mathrm{i} . \mathrm{p} .) \text { or } \mathrm{cfu} \mathrm{ml}^{-1}(\mathrm{immersion}) \text {. } \\
\text { Infective trials were carried out by i.p. injection and prolonged immersion }(1 \mathrm{~h}) \text {, maintaining fish in water at } 0.5 \% \text { salinity } \\
\text { and } 25^{\circ} \mathrm{C} \\
{ }^{b} \mathrm{CECT} \text {, Spanish Collection of Type Cultures }\end{array}$} \\
\hline
\end{tabular}


Table 2. Summary of Vibrio vulnificus serovar E vaccine formulations and vaccination procedures used in this study. i.p.: intraperitoneal

\begin{tabular}{|c|c|c|c|}
\hline Type of vaccine & Components & Inactivation procedure & Vaccination procedure \\
\hline \multirow[t]{2}{*}{$\begin{array}{l}\text { Whole-cell } \\
\text { bacterin (WCB) }\end{array}$} & $\begin{array}{l}\text { Opaque cells of CECT } 4604 \text { strain, } \\
\text { CECT } 4604 \text { (o) }\end{array}$ & $\begin{array}{l}\text { Formalin } \\
\text { (WCBFo, WCBFt) }\end{array}$ & i.p. injection \\
\hline & $\begin{array}{l}\text { Translucent cells of CECT } 4604 \text { strain, } \\
\text { CECT } 4604(\mathrm{t})\end{array}$ & $\begin{array}{l}\text { Formalin plus heating } \\
\text { (WCBHo, WCBHt) }\end{array}$ & Immersion $^{\mathrm{b}}$ \\
\hline \multirow[t]{2}{*}{$\begin{array}{l}\text { Toxoid-enriched } \\
\text { bacterin (TWCB) }\end{array}$} & $\begin{array}{l}\text { Cells and ECPs of CECT } 4604 \\
\text { (o) strain }\end{array}$ & $\begin{array}{l}\text { Formalin plus heating } \\
\text { (TWCBHo, TWCBHt) }\end{array}$ & i.p. injection \\
\hline & $\begin{array}{l}\text { Cells and ECPs of CECT } 4604 \\
\text { (t) strain }\end{array}$ & & Immersion \\
\hline $\begin{array}{l}\text { Virulence-attenuated } \\
\text { live cells vaccine (LCV) }\end{array}$ & Cells of NCIMB 2137 strain & None & Immersion \\
\hline LPS-based vaccine (LPSV) & $\begin{array}{l}\text { Purified LPS from CECT } 4604 \\
\text { strain }^{\text {a }}\end{array}$ & None & i.p. injection \\
\hline
\end{tabular}

heating $\left(60^{\circ} \mathrm{C}\right.$ for $\left.30 \mathrm{~min}\right)(\mathrm{WCBH})$. Inactivated cells were washed (centrifugation at $12000 \times g$ for $20 \mathrm{~min}$ at $4^{\circ} \mathrm{C}$ ) and finally resuspended in PBS-1 at a concentration of $8 \pm 0.5 \times 10^{9}$ cells ml ${ }^{-1}$ (absorbance at $600 \mathrm{~nm}$ of 0.75 ). The final concentration of formalin in readyto-use vaccine was $0.3 \%$.

The vaccine enriched with toxoids (TWCBH) was prepared by supplementing the $\mathrm{WCBH}$ with inactivated extracellular products (ECPs) from the strain CECT 4604, previously obtained using the cellophane plate technique of Liu (1957) with slight modifications (Amaro et al. 1992b). ECPs protein concentration was determined following Bradford's method (1976) with the Biorad reagent (Biorad Laboratories), using bovine serum albumin (Sigma) as the standard. The inactivation of ECPs was performed by heating $\left(80^{\circ} \mathrm{C}\right.$ for $15 \mathrm{~min})$. Formalin-killed cells were collected by centrifugation $\left(12000 \times g\right.$ for $20 \mathrm{~min}$ at $\left.4^{\circ} \mathrm{C}\right)$ and resuspended in inactivated ECPs at a final concentration of $8 \pm 0.5 \times$ $10^{9}$ cells $\mathrm{ml}^{-1}$. The final protein concentration in the vaccine was standardized to $0.3 \mathrm{mg} \mathrm{ml}^{-1}$.

For vaccination trials with virulence-attenuated livecell vaccine (LCV), $18 \mathrm{~h}$ cultures in Tryptic Soy Broth (Oxoid) supplemented with $0.5 \% \mathrm{NaCl}$ (TSB-1) of NCIMB 2137 strain (waterborne non virulent for eels [Amaro et al. 1995]) were used as immunogens. The concentration in the vaccination bath was about $1.0 \times$ $10^{7} \mathrm{cfu} \mathrm{ml}^{-1}$.

To prepare LPS vaccine, crude LPS from strain CECT 4604 was obtained from outer membrane fractions following the procedure developed by Filip et al. (1973) and modified by Amaro et al. (1992a). The presence of the endotoxin and the whole O-side chain was investigated by SDS-polyacrylamide gel electrophoresis
(SDS-PAGE) and immunostaining according to Amaro et al. (1992a). Samples of crude LPS were electrophoretically analyzed to test if they contain lipid A, and, finally, the cell fraction was resuspended in PBS-1 at a concentration of $2 \mathrm{mg} \mathrm{ml}^{-1}$ and frozen at $-80^{\circ} \mathrm{C}$ until use.

Quality control tests. Prior to vaccination, the sterility of inactivated whole-cell vaccines was confirmed by the absence of bacterial growth after the inoculation of the prepared bacterin in TSB-1 with $0.1 \mathrm{ml}$ aliquots (ratio1:9) and its incubation at $28^{\circ} \mathrm{C}$ for $1 \mathrm{wk}$. The lack of toxicity for eels was also evaluated by either i.p. injection $(0.1 \mathrm{ml}$ aliquots) or immersion in a bath of concentrated vaccine. The absence of remaining enzymatic activity after inactivation of ECPs was confirmed by means of the API ZYM system (Bio Merieux) according to the manufacturer's recommendations.

Fish. Elvers weighing an average of 8 to $10 \mathrm{~g}$, without a previous history of disease, were used. With only one exception (see Table 3), groups of 40 fish were used for each single experiment. Fish were fed on commercial diet during the experiments. Water salinity was $0.5 \%$ and temperature ranged from 25 to $28^{\circ} \mathrm{C}$.

Vaccination procedure. Immunization experiments with WCB and TWCB vaccines were carried out following 2 methods: (1) i.p. injection of $0.1 \mathrm{ml}$ of the vaccine (diluted to a concentration of $1 \times 10^{7} \mathrm{cells} \mathrm{ml}^{-1}$ ) per fish which, in the case of vaccines prepared with ECPs, contained Freund's complete adjuvant (FCA) (v/v) (Difco), and (2) direct immersion of the fish for $1 \mathrm{~h}$ in a bath containing the vaccine diluted to a concentration of about $1 \times 10^{7}$ cells ml-1 at a constant temperature of $26 \pm 1^{\circ} \mathrm{C}$ (Horne \& Ellis 1988). Two doses of vaccine were given by injection at $12 \mathrm{~d}$ intervals (Song et al. 1982). Two and 3 (booster effect) doses of vaccine 
Table 3. Protection of eels Anguilla anguilla against Vibrio vulnificus serovar E after vaccination by intraperitoneal (i.p.) injection with various $V$. vulnificus vaccines. RPS: relative percent of survival

\begin{tabular}{|c|c|c|c|c|}
\hline $\begin{array}{l}\text { Type of } \\
\text { vaccine }^{\mathrm{a}}\end{array}$ & $\begin{array}{l}\text { No. } \\
\text { fish }^{\mathrm{b}}\end{array}$ & $\begin{array}{l}\text { Mortality } \\
\text { i.p. }{\text { ' } / \text { bath }^{\mathrm{d}}}\end{array}$ & $\begin{array}{c}\text { RPS } \\
\text { i.p. } / \text { bath }^{\mathrm{f}}\end{array}$ & $\begin{array}{l}\text { Significance } \\
\text { i.p. }{ }^{9} / \text { bath }^{\mathrm{h}}\end{array}$ \\
\hline WCBFo & 40 & $20 / 0$ & $79.6 / 100$ & $+/+$ \\
\hline WCBFt & 40 & $44.4 / 10$ & $54.9 / 86.1$ & $+/+$ \\
\hline WCBHo & 40 & $25 / 0$ & $74.6 / 100$ & $+/+$ \\
\hline WCBHt & 40 & $46.5 / 11.1$ & $25.5 / 84.6$ & $+/+$ \\
\hline TWCBHo & 40 & $4.5 / 0$ & $92.7 / 100$ & $+/+$ \\
\hline TWCBHt & 40 & $49.9 / 0$ & $49.2 / 100$ & $+/+$ \\
\hline LPSV & 30 & $60.8 / 35.7$ & $2.72 / 11.4$ & $-1-$ \\
\hline Control (PBS-1) & 40 & $98.5 / 72.2$ & ND & ND \\
\hline $\begin{array}{l}\text { Control } \\
\text { (PBS-1+ FCA) }\end{array}$ & 40 & $62.5 / 40.3$ & ND & ND \\
\hline \multicolumn{5}{|c|}{${ }^{\mathrm{a}}$ Vaccine formulations: see Table 2} \\
\hline \multicolumn{5}{|c|}{${ }^{b}$ Number of vaccinated fish per group } \\
\hline \multicolumn{5}{|c|}{$\begin{array}{l}{ }^{\mathrm{c}} \text { Mean percentage of mortality after virulence challenge } \\
\text { by i.p. injection }\end{array}$} \\
\hline \multicolumn{5}{|c|}{$\begin{array}{l}\text { d Mean percentage of mortality after virulence challenge } \\
\text { by immersion }\end{array}$} \\
\hline \multicolumn{5}{|c|}{$\begin{array}{l}\text { eRPS between vaccinated and nonvaccinated fish chal- } \\
\text { lenged by i.p. injection }\end{array}$} \\
\hline \multicolumn{5}{|c|}{$\begin{array}{l}{ }^{\mathrm{f}} \text { RPS between vaccinated and nonvaccinated fish chal- } \\
\text { lenged by bath }\end{array}$} \\
\hline \multicolumn{5}{|c|}{$\begin{array}{l}{ }^{9} \text { Effect of the vaccination (cumulative survival of vaccinated } \\
\text { vs unvaccinated groups) after i.p. challenge: }+ \text {, positive } \\
\text { significance } \chi^{2}>3.841(\mathrm{n}=1, \mathrm{p}<0.05)_{i}-\text {, statistically not } \\
\text { significant }\end{array}$} \\
\hline \multicolumn{5}{|c|}{$\begin{array}{l}{ }^{\mathrm{h}} \text { Effect of the vaccination (cumulative survival of vaccinated } \\
\text { vs unvaccinated groups) after bath challenge: }+ \text {, positive } \\
\text { significance } \chi^{2}>3.841(\mathrm{n}=1, \mathrm{p}<0.05)_{i}-\text {, statistically not } \\
\text { significant }\end{array}$} \\
\hline
\end{tabular}

were administered by immersion at $7 \mathrm{~d}$ intervals (Song et al. 1982). Vaccine prepared with virulence-attenuated live cells was given only by immersion according to the procedure described above, while the one prepared with crude LPS was only administered by i.p. injection of $0.1 \mathrm{ml}$ of the vaccine $\left(0.2 \mathrm{mg} \mathrm{LPS} \mathrm{fish}^{-1}\right)$ containing FCA (v/v) (Salati \& Kusuda 1985, Saeed \& Plumb 1986). All vaccination experiments were performed in duplicate. Respective control groups were i.p. injected with $0.1 \mathrm{ml}$ per fish of PBS-1 or PBS$1+\mathrm{FCA}(\mathrm{v} / \mathrm{v})$ or immersed for $1 \mathrm{~h}$ in water, depending on the vaccination procedure tested.

Challenge. Two weeks after either each single vaccination or booster vaccination, 20 fish from each group (vaccinated and control) were artificially challenged with a single i.p. inoculation or an infective bath. For i.p. challenge, fish were injected with $0.1 \mathrm{ml}$ of a cell suspension of strain CECT 4604 (o) in PBS-1 adjusted to an individual dose equivalent to 10 times the mean lethal dose $\left(\mathrm{LD}_{50}\right)$ of the strain. Bath challenges were basically carried out as described by Amaro et al. (1995). Fish were immersed for $1 \mathrm{~h}$ in a bacterial solution (final dose of $10 \times \mathrm{LD}_{50}$ ) in water at $1 \%$ of salinity with con- stant aeration, maintaining the temperature around $26 \pm 1^{\circ} \mathrm{C}$. Non-infected groups of fish, challenged with sterile PBS-1 (i.p. injection) or TSB-1 (bath), were also included. Mortalities were recorded daily during periods of 8 or $14 \mathrm{~d}$ in injection or bath challenges, respectively. Samples of the kidney, liver and skin from moribund fish were taken aseptically and analyzed to confirm the cause of death. Mortalities were considered to be due to septicemia if the challenged strain was isolated as pure culture from internal organ and identified by slide agglutination with specific sera (Amaro et al. 1992b). The efficacy of vaccination was evaluated by calculating the RPS as 1 - (\% mortality in vaccinated fish $/ \%$ mortality in controls) $\times 100$ (Amend 1981).

Statistical analysis. The chi-square test was used to analyze the differences in survival after challenge between vaccinated and non-vaccinated groups (each vaccine was tested against its corresponding control, PBS-1 or PBS-1 plus FCA), and between different treatments using a significance level of $\mathrm{p}<0.05$ (Milton \& Tsokos 1989).

Specific immune response. A week after administering the last dose of the vaccine, serum and skin mucus were collected from 6 to 8 eels from both vaccinated and control groups and pooled (1 sample per group). Serum was obtained as described previously (Biosca et al. 1993b) and skin mucus was collected by placing fish in sterile flasks for approximately $5 \mathrm{~min}$. After removing fish, the mucous material within each flask was collected and filtered through 0.8 and $0.45 \mu \mathrm{m}$ poresize membranes (Millipore). Both kinds of samples were stored at $-80^{\circ} \mathrm{C}$ until use.

Antibody levels in serum and skin mucus: Antibody titers in serum or skin mucus against whole cells of CECT 4604 strain were determined by using a standard microagglutination procedure (Roberson 1990) and an indirect enzyme-linked immunoadsorbent assay (ELISA). For the ELISA, wells of flat-bottomed plates (Nunc-ELISA Maxisorp) were coated for $2 \mathrm{~h}$ at $69^{\circ} \mathrm{C}$ with $100 \mu \mathrm{l}$ of a suspension of strain CECT 4604 in PBS-1 (10 cells ml $\left.{ }^{-1}\right)$ (Biosca et al. 1997b). Wells were washed 3 times with PBST (PBS-1+ 0.05\% Tween 20 [v/v]) for $2 \mathrm{~min}$ (this washing procedure was repeated between each step). Antigen-coated plates were then incubated for $1 \mathrm{~h}$ at $28^{\circ} \mathrm{C}$ with $100 \mu \mathrm{l}$ of serial 2-fold dilutions of mucus extract or fish serum in PBST-BSA (PBST $+1 \%$ bovine serum albumin [wt/v]), washed and incubated for $1 \mathrm{~h}$ at $37^{\circ} \mathrm{C}$ with rabbit anti-eel serum (1:1000), obtained as previously described by Amaro et al. (1997). Finally, wells were incubated for $1 \mathrm{~h}$ at $37^{\circ} \mathrm{C}$ with alkaline phosphatase-conjugated goat anti-rabbit immunoglobulins (Biorad) diluted in PBST-BSA (1:2000) and developed with p-nitrophenyl phosphate (diluted in diethanolamine buffer, $\mathrm{pH} 8$, at a concentration of $1 \mathrm{mg} \mathrm{ml}^{-1}$ ) as substrate. Absorbance values were deter- 
mined after incubating plates for $1 \mathrm{~h}$ at $37^{\circ} \mathrm{C}$ in the dark using a microplate reader (Multiscan microtiter plate reader) set at $405 \mathrm{~nm}$. Positive reaction was set at an optical density (OD) equal to or greater than 0.2 after subtraction of values for negative controls (samples from non-immunized eels).

Bacterial survival in serum and skin mucus: Bactericidal and bacteriostatic activities in serum or skin mucus from vaccinated and unvaccinated eels were measured as the survival percentage of the CECT 4604 strain in these fluids, according to the procedure set out by Amaro et al. (1997). Briefly, stationary-phase bacteria resuspended in PBS-1 were inoculated in duplicate in samples of mucus and serum from vaccinated and control eels at a level of around $10^{5}$ colony forming units (cfu) $\mathrm{ml}^{-1}$ and incubated at $25^{\circ} \mathrm{C}$ for $4 \mathrm{~h}$. Viable-cell counts were determined by drop plating serial dilutions on TSA-1 (Hoben \& Somasegaran 1982).

Dot blot assay. Thermostable ' $\mathrm{O}$ ' antigens (whole cell extract after heating at $100^{\circ} \mathrm{C}$ for $2 \mathrm{~h}$ ), outer membrane proteins (OMPs), crude LPS and ECPs were obtained from strain CECT 4604 as previously described (Amaro et al. 1992b, Biosca et al. 1993a, Biosca et al. 1996). Purified LPS was obtained by the water-phenol procedure of Westphal \& Jann (1965). The presence of the endotoxin and the whole $\mathrm{O}$-side chain was investigated by SDS-PAGE and immunostaining according to Amaro et al. (1992a). Thermostable 'O' antigens from strain CECT 4606 of Vibrio vulnificus biotype 1 were also obtained. Indirect dot blot assays were performed by the method described by Burreson \& Frizzell (1986) and Cipriano et al. (1985) with some modifications (Amaro et al. 1997). Briefly, antigens (whole-cells $\left[10^{6}\right.$ cells], ECPs [1 $\mu \mathrm{g}$ of protein], 'O' antigens $\left[10^{6}\right.$ cells], OMPs [1 $\mu \mathrm{g}$ ], crude LPS [1 $\mu \mathrm{g}$ ], and purified LPS [1 $\mu \mathrm{g}]$ ] were fixed on nitrocellulose papers. Membranes were incubated with eel serum, and immunological reactions were revealed as previously described (Amaro et al. 1997). Whole cells of strain HB-101 of Escherichia coli were used as a negative control.

\section{RESULTS}

\section{Protection of eels vaccinated by injection}

To evaluate the degree of protection, we compared survival percentages between vaccinated eels and controls inoculated with PBS-1 or PBS-1 plus FCA (in the case of vaccines containing LPS or inactivated ECPs). With the exception of LPS vaccine, all the vaccine formulations gave a significant protection after delivering 2 doses, regardless of the virulence challenge procedure (Table 3). The RPS values were always higher when the pathogen was challenged by bath than by i.p. injection (Table 3). Crude LPS samples used for vaccination contained the endotoxin and the whole O-side chain (data not shown). Eels immunized with the oil-adjuvanted LPS vaccine were slightly protected, but no significant difference was detected when compared to the controls ( $p>0.05$ ). With regard to the inactivation procedure, no significant difference was found between treatment with formalin and treatment with formalin plus heating $(\mathrm{p}>$ 0.05). In all cases, the vaccines prepared from capsulated whole-cells (WCBFo, WCBHo and TWCBHo) were more effective than those prepared from uncapsulated cells (WCBFt, WCBHt and TWCBHt) (Table 3) and this difference was statistically significant $(\mathrm{p}<$ 0.05). In fact, when opaque bacterins were used, an RPS of $100 \%$ was achieved after bath challenge of the pathogen. When RPS was less than $100 \%$, a significant increase of protection $(\mathrm{p}<0.05)$ was detected after the enrichment of the vaccines with toxoids (Table 3 ). Taking all these data together, the optimal protection was provided by the toxoid-enriched capsulated whole-cell vaccine, with RPS values of 93 and $100 \%$ after i.p. and bath challenge, respectively.

\section{Effect of booster on vaccination by immersion}

Two highly effective bacterins (WCBFo and WCBHo) were selected to assay the booster effect when they were administered by prolonged immersion. Results of the immersion vaccination experiments are illustrated in Fig. 1. Although eels responded after a double exposure to the vaccine, a triple one resulted in increased protection: the RPS obtained after bath challenge with the pathogen (around 70\%) was significantly higher than those found in fish doubly exposed to vaccine

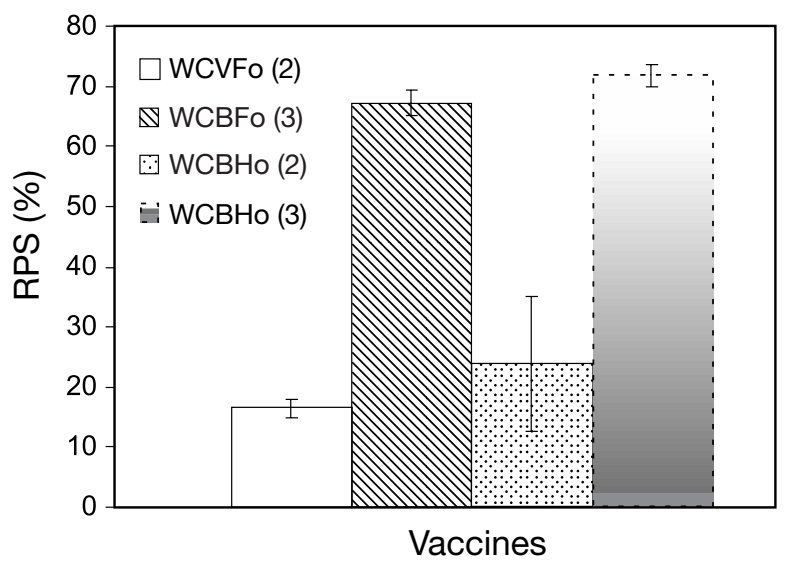

Fig. 1. Effect of number of doses of Vibrio vulnificus serovar E vaccines delivered by prolonged immersion on the level of protection of eels, measured as the relative percent survival (RPS) 
(RPS around 20\%) (Fig. 1). Therefore, the subsequent immersion experiments were performed exposing eels to the different vaccines 3 times. The temperature of the vaccination bath $\left(26 \pm 1^{\circ} \mathrm{C}\right)$ was adequate for eels to develop satisfactory protection.

\section{Protection of eels vaccinated by immersion}

Eels were protected against Vibrio vulnificus serovar $E$ after the administration of a triple dose of the vaccines by prolonged immersion (Table 4). In all cases, the differences in survival between vaccinated and control animals were statistically significant according to chi-square analysis (Table 4). As occurred in injection vaccination, the vaccines prepared with capsulated cells were the most effective ones (Table 4), but the difference in RPS with translucent vaccines was only statistically significant when the pathogen was i.p. challenged (Table 4). The effect of the addition of toxoids on improving protection was not significant ( $p>0.05)$. The RPS values of eels immunized with the live vaccine (derived from the strain NCIMB 2137 constitutively translucent and avirulent by bath challenge)

Table 4. Protection of eels Anguilla anguilla against Vibrio vulnificus serovar E after vaccination by prolonged immersion (3 doses) with various $V$. vulnificus vaccines. i.p.: intraperitoneal; RPS: relative percent survival

\begin{tabular}{|c|c|c|c|c|}
\hline $\begin{array}{l}\text { Type of } \\
\text { vaccine }^{\mathrm{a}}\end{array}$ & $\begin{array}{l}\text { No. } \\
\text { fish }^{\text {b }}\end{array}$ & $\begin{array}{l}\text { Mortality } \\
\text { i.p. } / \text { bath }^{\mathrm{d}}\end{array}$ & $\begin{array}{l}\text { RPS } \\
\text { i.p. } / \text { bath }^{\mathrm{f}}\end{array}$ & $\begin{array}{l}\text { Significance } \\
\text { i.p. }{ }^{\mathrm{g}} / \mathrm{bath} \mathrm{b}^{\mathrm{h}}\end{array}$ \\
\hline WCBFo & 40 & $50 / 22.2$ & $49.2 / 69.2$ & $+/+$ \\
\hline WCBFt & 40 & $70 / 25.1$ & 28.9/65.1 & $+/+$ \\
\hline WCBHo & 40 & $41.6 / 19.1$ & $57.7 / 73.5$ & $+/+$ \\
\hline WCBHt & 40 & $60.5 / 28.3$ & $38.5 / 60.8$ & $+/+$ \\
\hline TWCBHo & 40 & $52.3 / 21.4$ & $46.8 / 70.3$ & $+/+$ \\
\hline TWCBHt & 40 & $58.3 / 37.5$ & $40.7 / 48$ & $+/+$ \\
\hline LCV & 40 & $75.0 / 30.1$ & $23.8 / 58.3$ & $+/+$ \\
\hline $\begin{array}{l}\text { Control } \\
\text { (PBS-1/TSB-1) }\end{array}$ & 40 & $98.5 / 72.2$ & - & - \\
\hline \multicolumn{5}{|c|}{${ }^{a}$ Vaccine formulations: see Table 2} \\
\hline \multicolumn{5}{|c|}{${ }^{\mathrm{b}}$ Number of vaccinated fish per group } \\
\hline \multicolumn{5}{|c|}{$\begin{array}{l}{ }^{\mathrm{c}} \text { Mean percentage of mortality after virulence challenge } \\
\text { by i.p. injection }\end{array}$} \\
\hline \multicolumn{5}{|c|}{$\begin{array}{l}{ }^{\mathrm{d}} \text { Mean percentage of mortality after virulence challenge } \\
\text { by bath }\end{array}$} \\
\hline \multirow{2}{*}{\multicolumn{5}{|c|}{$\begin{array}{l}\text { e RPS between vaccinated and nonvaccinated fish chal- } \\
\text { lenged by i.p. injection } \\
{ }^{\mathrm{f}} \text { RPS between vaccinated and nonvaccinated fish chal- } \\
\text { lenged by bath }\end{array}$}} \\
\hline & & & & \\
\hline \multicolumn{5}{|c|}{$\begin{array}{l}{ }^{g} \text { Effect of the vaccination (cumulative survival of vacci- } \\
\text { nated vs unvaccinated groups) after i.p. challenge: }+ \text {, } \\
\text { positive significance } \chi^{2}>3.841(\mathrm{n}=1, \mathrm{p}<0.05)_{i}-\text {, statis- } \\
\text { tically not significant }\end{array}$} \\
\hline \multicolumn{5}{|c|}{$\begin{array}{l}{ }^{\mathrm{h}} \text { Effect of the vaccination (cumulative survival of vacci- } \\
\text { nated vs unvaccinated groups) after bath challenge: }+ \text {, } \\
\text { positive significance } \chi^{2}>3.841(\mathrm{n}=1, \mathrm{p}<0.05) ;- \text {, statis- } \\
\text { tically not significant }\end{array}$} \\
\hline
\end{tabular}

were similar to those obtained with bacterins derived from translucent inactivated cells (Table 4). As occurred for i.p. vaccination, the RPS values after bath challenge were higher than after injection challenge. In general, the inactivation with formalin and heating resulted in a slightly higher level of protection, although the differences between these and those inactivated only with formalin were not significant ( $p>0.05)$.

\section{Immune response of vaccinated eels}

Bactericidal/bacteriostatic effect of serum and mucus

Strain CECT 4604 of Vibrio vulnificus serovar E survived in samples of serum and skin mucus from unvaccinated eels under the conditions assayed (Figs. 2 \& 3). However, the fate of bacterial cells in serum and mucus from vaccinated eels was variable, depending on the vaccination procedure. Sera from injection vaccinated eels showed bactericidal activity, especially sera from fish vaccinated with TWCBHo (Fig. 2A). However, the pathogen survived in sera from immersion vaccinated eels, with the exception of the sera from fish vaccinated with live-cell vaccine, which showed a slight bactericidal activity (Fig. 2B). In contrast, cells survived and multiplied in skin mucus from injection vaccinated eels (Fig. 3A) but were sensitive to the bactericidal activity of mucus from immersion vaccinated eels, regardless the type of vaccine (Fig. 3B).
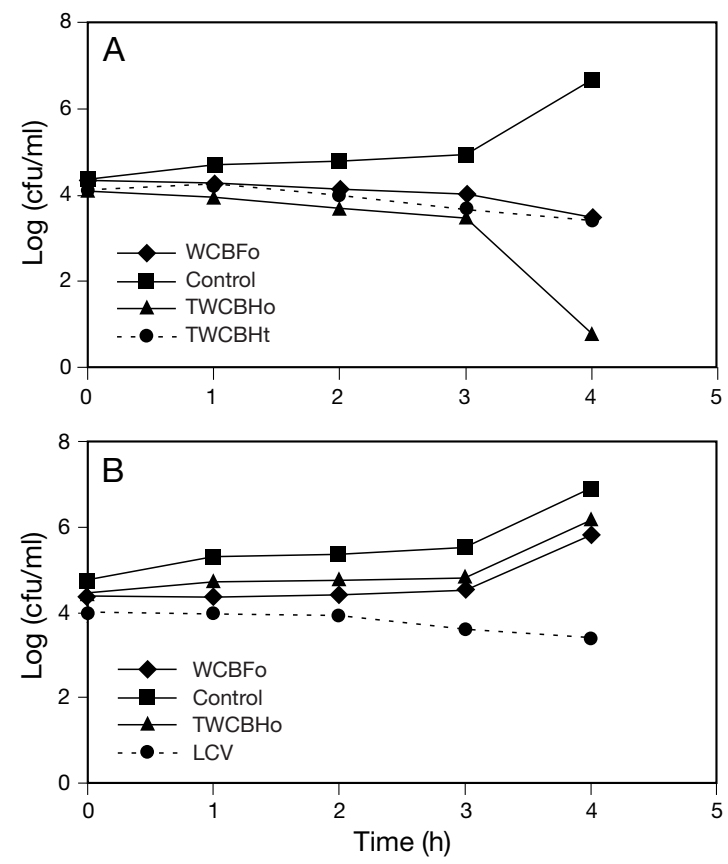

Fig. 2. Survival of capsulated cells of strain CECT 4604 of Vibrio vulnificus serovar $\mathrm{E}$ in serum obtained from eels immunized by either (A) intraperitoneal injection or (B) immersion 

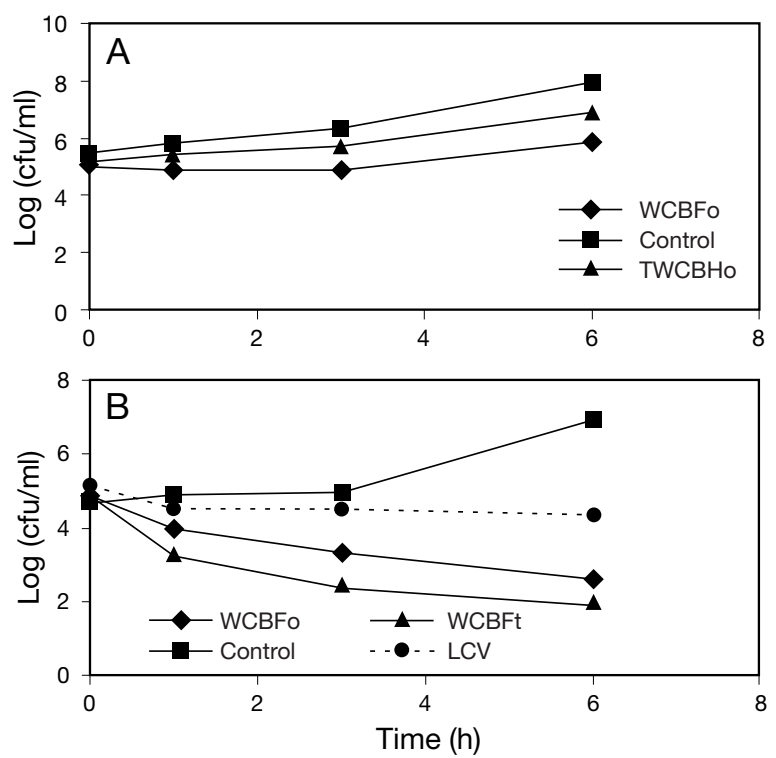

Fig. 3. Survival of capsulated cells of strain CECT 4604 of Vibrio vulnificus serovar $\mathrm{E}$ in skin mucus obtained from eels immunized by either (A) intraperitoneal injection or (B) immersion

\section{Effect of vaccination on antibody levels}

The immunized fish exhibited a specific humoral response, with antibody titers varying depending on the vaccine formulation and the vaccination procedure. Titers obtained by ELISA are shown in Table 5. In serum, the highest titers were found in eels vaccinated by injection, whereas in mucus the highest titers were found after immersion (Table 5). With respect to

Table 5. Antibody titers in eels Anguilla anguilla vaccinated with various Vibrio vulnificus serovar E vaccines by intraperitoneal (i.p.) injection and prolonged immersion (3 doses)

\begin{tabular}{|c|c|c|c|c|}
\hline \multirow[t]{2}{*}{$\begin{array}{l}\text { Type of } \\
\text { vaccine }^{a}\end{array}$} & \multicolumn{2}{|c|}{$\begin{array}{l}\text { Antibody titer } \\
\text { in serum }^{\mathrm{b}}\end{array}$} & \multicolumn{2}{|c|}{$\begin{array}{l}\text { Antibody titer } \\
\text { in mucus }\end{array}$} \\
\hline & i.p. & Immersion & i.p. & Immersion \\
\hline WCBFo & 1200 & $<50$ & $<2$ & 4 \\
\hline WCBFt & 600 & $<50$ & $<2$ & 4 \\
\hline WCBHo & 2400 & $<50$ & $<2$ & $<2$ \\
\hline WCBHt & 300 & $<50$ & $<2$ & $<2$ \\
\hline TWCBHo & 48000 & 200 & $<2$ & 16 \\
\hline TWCBHt & 36000 & 200 & $<2$ & 16 \\
\hline LPSV & 3200 & - & $<2$ & - \\
\hline LCV & - & 150 & - & $<2$ \\
\hline \multicolumn{5}{|c|}{ a Vaccine formulations: see Table 2} \\
\hline \multicolumn{5}{|c|}{$\begin{array}{l}{ }^{\mathrm{b}} \text { Titer of antibody against } V \text {. vulnificus serovar E strain } \\
\text { CECT } 4604 \text { determined by ELISA. Titer was expressed as } \\
\text { the reciprocal of the highest dilution giving a positive } \\
\text { response. Positive reaction was set at an OD equal to or } \\
\text { greater than } 0.2 \text { after subtraction of values for negative } \\
\text { controls (samples from non immunized eels) }\end{array}$} \\
\hline
\end{tabular}

the vaccine formulation, the use of opaque cells instead of translucent ones increased antibody titers in the serum. These increased spectacularly when toxoids were added to the vaccine (from 300/2400 to $36000 / 48000$ for eels vaccinated by injection, and from $<1: 50$ to $1: 200$ for eels immunized by immersion) (Table 5). Titers obtained by microagglutination were always lower than those obtained by ELISA. These titers ranged from 1:4 to 1:8 for fish injected with WCB or LPSV, from 1:64 to 1:128 for fish injected with toxoid-enriched vaccines, and from 1:2 to 1:4 for fish vaccinated by immersion. There were no significant differences between titers obtained after a double or a triple immersion exposure to the vaccines (data not shown).

A very low antibody response was detected in mucus by both ELISA and microagglutination. Samples from injection vaccinated eels were negative in both assays (titer <1:2), and samples from immersion-vaccinated eels showed antibody titers from $<1: 2$ to $1: 16$ (Table 5) by ELISA, and <1:2 by microagglutination, regardless of the route of delivery and the vaccine tested. Analogous to the serum, the highest antibody levels were detected in mucus from fish immunized with toxoidenriched bacterins.

\section{Antibody recognition of specific antigens}

The bacterial antigens recognized by immune sera were investigated with an indirect dot blot assay using pooled sera from unvaccinated and injection vaccinated fish as negative and positive standards, respectively. Sera from i.p. immunized eels reacted specifically with whole cells, 'O' antigen, crude LPS, OMP extract and ECPs from CECT 4604 strain, but did not recognize the purified LPS of this strain (Fig. 4). The

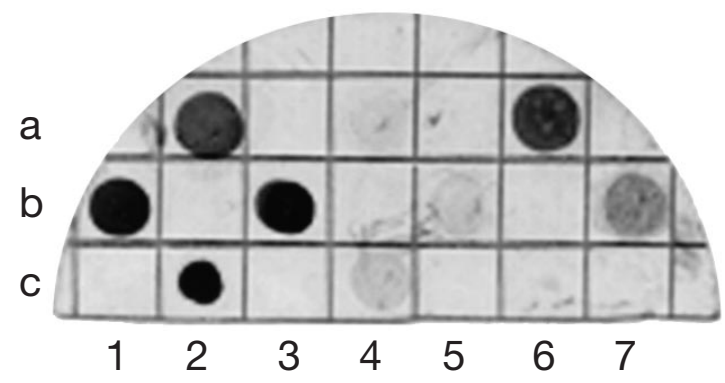

Fig. 4. Recognition of specific antigens by serum from injection-vaccinated eels with a toxoid-enriched bacterin against Vibrio vulnificus serovar E using an indirect dot blot assay. a2: whole cells of CECT 4604; a4: whole cells of CECT 4606; a6: 'O' antigen of CECT 4606; b1: 'O' antigen of CECT 4604; b3: crude LPS of CECT 4604; b5: purified LPS of CECT 4604; b7: ECPs of CECT 4604; c2: OMPs of CECT 4604; c4: whole cells of Escherichia coli HB-101; c6, PBS-1 
purified LPS samples were enriched in the endotoxic fraction and lacked most of O-side chains, specially those of the highest molecular weight (data not shown). In contrast, sera from immersion vaccinated fish only reacted against ' $\mathrm{O}$ ' antigen from CECT 4604 strain (results not shown). Although whole cells of biotype 1 were not recognized, the ' $\mathrm{O}$ ' antigen strongly reacted with sera from i.p. immunized eels (Fig. 4). In general, whole cells, 'O' antigens and OMP extracts of serovar $\mathrm{E}$ were better recognized than the ECPs by sera from injection-vaccinated eels (Fig. 4).

\section{DISCUSSION}

The majority of the vaccine formulations developed in the present study protected eels against Vibrio vulnificus serovar E when they were administered by either i.p. injection or prolonged immersion. For vaccination experiments we selected a water temperature of around $26^{\circ} \mathrm{C}$, the average temperature used in intensive eel culture facilities. At this temperature, the immune system in eels with a body weight of around $10 \mathrm{~g}$ worked well enough to defend them against vibriosis due to $V$. vulnificus.

Firstly, we tested different formulations of whole-cell vaccines (capsulated- and uncapsulated-cell bacterins, either enriched or not with toxoids), 2 procedures of cell inactivation (treatment with formalin, with and without heating), and 2 delivery methods (i.p. injection and immersion). It has been reported that heating can induce antigenic changes and produce a decrease in RPS values (Al-Harbi \& Austin 1993). However, we did not find significant differences in the degree of protection depending on the cell inactivation procedure. In accordance with numerous reports, the effectiveness of the vaccination was dependent on the route of administration, and was significantly higher when vaccination was carried out by injection (Song \& Kou 1981, Velji et al. 1990, Loghothetis \& Austin 1994, Palm et al. 1998, Kim et al. 2000). This difference may be due to the lower amount of antigen absorbed by eels when the vaccine is administered by immersion. This could also explain why the RPS values obtained were higher after a bath challenge.

All vaccines containing capsulated cells conferred higher degrees of protection than the homologous ones prepared with uncapsulated cells, irrespective of the route of administration. The RPS was $100 \%$ for opaque bacterins delivered by injection and tested by bath challenge. Capsule is an essential virulence factor for this pathogen: it confers resistance to human serum and phagocytosis (Biosca et al. 1993b, Amaro et al. 1994, 1997), and the ability to infect eels through water (Amaro et al. 1995). Our results demonstrate that the presence of capsular antigens in the vaccine formulation significantly enhances the degree of protection.

We also tested the role of toxoids as immunoprotective antigens. This role has been demonstrated for vibriosis caused by Vibrio anguillarum and pasteurellosis (Santos et al. 1991, Magariños et al. 1994). V. vulnificus serovar E produces thermolabile exotoxins and exoenzymes, mainly hemolysins and proteases, which are highly toxic for eels, that are essential virulence factors (Biosca \& Amaro 1996). The effect of the addition of toxoids to bacterins was variable, depending on the route of administration. Toxoids significantly increased immunoprotection only when vaccines were i.p. delivered, with RPS values higher than $90 \%$ even when the pathogen was i.p. challenged. These results could suggest that toxoids were not well absorbed through skin and gills, or that the concentration tested was not suitable for immersion immunization. In fact, our recent results, working with an improved vaccine, seem to support the last suggestion (authors' unpubl. data). Therefore, the effectiveness of the tested vaccines was dependent on their formulation, with capsular antigens and toxoids playing a decisive role in the protective immunity induced in eels.

We also tested the efficacy of LPS-based and attenuated live vaccines. LPS is an essential virulence factor for Vibrio vulnificus serovar E, conferring resistance to eel serum complement (Amaro et al. 1997). However, survival of eels immunized with the LPS-based vaccine was not significantly different from that of the control groups. This result could suggest that LPS from $V$. vulnificus serovar $\mathrm{E}$ is not a protective immunogen for eels, at least at the assayed concentration. Similar results have been reported for Japanese eels immunized with LPS from Edwardsiella tarda (Gutiérrez \& Miyazaki 1994). However, both results contrast with those reported for other fish species that become well protected against several bacterial diseases after immunization with LPS-based vaccines (Fukuda \& Kusuda 1985, Salati \& Kusuda 1985, Velji et al. 1990). LCV was prepared with strain ATCC 2137 that is avirulent by bath, because it lacks capsule (Amaro et al. 1995). The results on eel protection were similar to those obtained with translucent-cell bacterins. This finding supports that cells in LCV need to be capsulated to induce a good protection and confirms the role of capsule as protective immunogen.

When vaccines were administered by prolonged immersion a triple exposure was needed to achieve a significant protection. This method of delivery is quicker, easier, more economical and less stressing than the injection method and could be used in eel culture facilities. Some authors have reported that delivering only 2 doses is enough to achieve similar protec- 
tion in other fish species (Song et al. 1982, Magariños et al. 1994, 1999, Gravningen et al. 1998, Palm et al. 1998).

Serum and skin mucus of fish contain antibodies, complement, etc. (Rombout et al. 1986, Austin \& McIntosh 1988, Itami 1993) and act as lines of defense against pathogenic microorganisms. The results of this study have shown that antibody titers exhibited by fish immunized with the different vaccines were moderate or high in serum and low or nearly absent in mucus. We did not find a significant increase in antibody titers after the third administration by immersion, but we can not conclude that eels lack anamnesic response. In fact, further experiments performed by our research team confirm that the antibody levels increase spectacularly when immunized fish are exposed to low doses of the pathogen (data not shown). Serum from injection vaccinated fish mainly reacted against whole capsulated cells, 'O' antigens, crude LPS and OMP fractions of Vibrio vulnificus serovar E, which is evidence of their effective role in inducing specific humoral response. This serum also recognized ' $\mathrm{O}$ ' antigen of strain CECT 4606, which do not belong to serovar E. This result suggests that vaccinated eels could develop immunity against other $V$. vulnificus serovars. The immune serum did not react against purified LPS. As we mentioned before, purified LPS samples obtained by the water-phenol procedure of Westphal \& Jann (1965) were enriched in the endotoxic fraction, lacking most of O-side bands. These findings support that the endotoxin is not immunogenic and the $\mathrm{O}$-side chain is. In serum, and depending on the vaccine, antibody titers were low or moderate $(\leq 1: 200)$ in immersion-vaccinated fish, and high (ranging from 1:300 to 1:48000) in injection-vaccinated fish. In the latter cases, a positive correlation between the level of antibodies and protection was observed, since the highest titers were found in sera from eels immunized with the most protective vaccines. This fact suggests the strong influence that the route of delivery has on the magnitude of specific humoral response, as previously found in other fish species vaccinated against vibriosis (Palm et al. 1998). This influence was also observed in mucus, but in contrast to that found in serum, the route that elicited a specific, but low (titers of 1:4 to 1:16), humoral response was prolonged immersion. Similar results have been found in other fishes that showed negative results in cutaneous mucus after injection vaccination (Cobb et al. 1998). The dilution of mucus, due to the sampling procedure, could partially explain the low antibody levels, but it is also possible that the secretory immunoglobulins were not well recognized by our ELISA.

We evaluated the bactericidal/bacteriostatic effect against Vibrio vulnificus serovar E in mucus and serum samples. The results indicate that the vaccine's route of delivery also influences these effects. Bacterial cells were sensitive only to sera from injection vaccinated eels and mucus from immersion vaccinated eels. These findings suggest the existence of a local immune response in eels, with probably different kinetics than that of the systemic response. Although the intensity of the bactericidal effect was related to the antibody level, the specific nature of the inhibitory effect observed in serum and mucus from vaccinated eels has yet to be determined.

In summary, our results demonstrate that a protective response against Vibrio vulnificus serovar E is induced in vaccinated eels under laboratory conditions. Among the different vaccine formulations tested, the toxoid-enriched bacterin prepared with capsulated cells was the most effective one, delivered by either injection or immersion. The protective effect in serum and mucus depends on the route of administration, and seems to be related to the production of specific antibodies. Since the presence of $V$. vulnificus represents a threat to susceptible fish species, vaccination of glass eels by immersion upon being brought into culture facilities could be the best strategy to prevent epizootic outbreaks in future. Further field studies are necessary to validate the developed vaccines for large-scale use.

Acknowledgements. This work has been financed by projects PETRI 95-0070-OP and CICYT IFD97-0800 from the Ministerio de Educación y Ciencia, Spain. We thank Rafael Ruano and José Tornero from the Generalitat Valenciana for supplying eels for immunization. We also thank BarracloughDonnellan for their help with the English text.

\section{LITERATURE CITED}

Al-Harbi AH, Austin B (1993) The immune response of turbot (Scophthalmus maximus L.) to formolized and heat inactivated cells, and subcellular components of a fish pathogenic Cytophaga-like bacterium (CLB). Bull Eur Assoc Fish Pathol 13:21-24

Amaro C, Biosca EG (1996) Vibrio vulnificus biotype 2, pathogenic for eels, is also an opportunistic pathogen for humans. Appl Environ Microbiol 62:1454-1457

Amaro C, Biosca EG, Esteve C, Fouz B, Garay E (1992a) Electrophoretic analysis of heterogeneous lipopolysaccharides from various strains of Vibrio vulnificus biotypes 1 and 2 by silver staining and immunoblotting. Curr Microbiol 25:99-104

Amaro C, Biosca EG, Esteve C, Fouz B, Toranzo AE (1992b) Comparative study of phenotypic and virulence properties in Vibrio vulnificus biotype 1 and 2 obtained from a European eel farm experiencing mortalities. Dis Aquat Org 13:29-35

Amaro C, Biosca EG, Fouz B, Toranzo AE, Garay E (1994) Role of iron, capsule, and toxins in the pathogenicity of Vibrio vulnificus biotype 2 for mice. Infect Immun 62: 759-763

Amaro C, Biosca EG, Fouz B, Alcaide E, Esteve C (1995) 
Evidence that water transmits Vibrio vulnificus biotype 2 infections to eels. Appl Environ Microbiol 61:1133-1137

Amaro C, Fouz B, Biosca EG, Collado RM, Marco-Noales E (1997) The lipopolysaccharide O side chain of Vibrio vulnificus serogroup $\mathrm{E}$ is a virulence determinant for eels. Infect Immun 65:2475-2479

Amend D (1981) Potency testing of fish vaccines. Dev Biol Stand 49:447-454

Austin A (1983) Vaccine for the control of vibriosis in eels. Vet Rec 22:394-395

Austin B, Austin DA (1993) Vibrionaceae representatives. In: Laird LM (ed) Bacterial fish pathogens. Ellis Horwood Ltd, Chichester, England, p 265-294

Austin B, MacIntosh D (1988) Natural antibacterial compounds on the surface of rainbow trout, Salmo gairdneri Richardson. J Fish Dis 11:275-277

Biosca EG (1994) Serología y virulencia de Vibrio vulnificus biotipo 2. PhD thesis. Universidad de Valencia, Valencia

Biosca EG, Amaro C (1996) Toxic and enzymatic activities of Vibrio vulnificus biotype 2 with respect to host specificity. Appl Environ Microbiol 62:2331-2337

Biosca EG, Amaro C, Esteve C, Alcaide E, Garay E (1991) First record of Vibrio vulnificus biotype 2 from diseased European eel, Anguilla anguilla L. J Fish Dis 14:103-109

Biosca EG, Garay E, Toranzo AE, Amaro C (1993a) Comparison of the outer membrane profile of Vibrio vulnificus biotypes 1 and 2. FEMS Microbiol Lett 107:217-222

Biosca EG, Llorens H, Garay E, Amaro C (1993b) Presence of a capsule in Vibrio vulnificus biotype 2 and its relationship to virulence for eels. Infect Immun 61:1611-1618

Biosca EG, Oliver JD, Amaro C (1996) Phenotypic characterization of Vibrio vulnificus biotype 2, a lipopolysaccharidebased homogeneous serogroup within Vibrio vulnificus. Appl Environ Microbiol 62:918-927

Biosca EG, Amaro C, Larsen JL, Pedersen K (1997a) Phenotypic and genotypic characterization of Vibrio vulnificus: proposal for the substitution of the subspecific taxon for serovar. Appl Environ Microbiol 63:1460-1466

Biosca EG, Marco-Noales E, Amaro C, Alcaide E (1997b) An enzyme-linked immunosorbent assay for detection of Vibrio vulnificus biotype 2: development and field studies. Appl Environ Microbiol 63:537-542

Bradford MM (1976) A rapid and sensitive method for the quantitation of microgram quantities of protein utilizing the principle of protein-dye binding. Anal Biochem 72: 248-254

Burreson EM, Frizell LJ (1986) The seasonal antibody response in juvenile summer flounder (Paralychthys dentatus) to the hemoflagellate Tripanoplasma bullocki. Vet Immunol Immunopathol 12:395-402

Cipriano RC, Pyle JB, Starliper CE, Pyle SW (1985) Detection of Vibrio anguillarum antigen by the dot blot assay. J Wildl Dis 21:211-218

Cobb CS, Levy MG, Noga EJ (1998) Acquired immunity to amyloodiniosis is associated with antibody response. Dis Aquat Org 34:125-133

Dalsgaard I, Hoi L, Siebeling RJ, Dalsgaard A (1998) Indolepositive Vibrio vulnificus isolated from disease outbreaks on a Danish eel farm. Dis Aquat Org 35:187-194

Dec C, Angelidis P, Baudin FL (1990) Effects of oral vaccination against vibriosis in turbot, Scophthalmus maximus (L.) and sea bass, Dicentrachus labrax (L.). J Fish Dis 13: 369-376

Filip C, Fletcher G, Wulf JL, Earhart CF (1973) Solubilization of the cytoplasmic membrane of Escherichia coli by the ionic detergent, sodium lauryl sarkosynate. J Bacteriol $115: 717-722$
Fukuda Y, Kusuda R (1985) Vaccination of yellowtail against pseudotuberculosis. Fish Pathol 20:421-425

Gotschlich EC (1993) Immunity to extracellular bacteria. In: Paul WE (ed) Fundamental immunology. Raven Press Ltd, New York, p 1287-1298

Gravningen K, Thorarinsson R, Johansen LH, Nissen B, Rikardsen KS, Greger E, Vigneulle M (1998) Bivalent vaccines for sea bass (Dicentrachus labrax) against vibriosis and pasteurellosis. J Appl Ichthyol 14:159-162

Gutiérrez MA, Miyazaki, T (1994) Responses of Japanese eels to oral challenge with Edwarsiella tarda after vaccination with formalin-killed cells or lipopolysaccharide of the bacterium. J Aquat Anim Health 6:110-117

Hoben HJ, Somasegaran P (1982) Comparison of the pour, spread and drop plate methods for enumeration of Rhizobium spp. in inoculants made from presterilized peat. Appl Environ Microbiol 44:1246-1247

Høi L (1999) Vibrio vulnificus in Denmark, ocurrence, isolation and characterization. PhD thesis, Department of Veterinary Microbiology, The Royal Veterinary and Agricultural University, Copenhagen, Denmark

Horne MT, Ellis AE (1988) Strategies of fish vaccination. In: Ellis AE (ed) Fish vaccination. Academic Press Ltd, London, p 67-84

Itami I (1993) Defense mechanism of Ayu skin mucus. J Shimonoseki Univ Fish 42:1-71

Kim KH, Hwang YJ, Cho JB, Park S II (2000) Immunization of cultured juvenile rockfish Sebastes schlegeli against Microcotyle sebastis (Monogea). Dis Aquat Org 40:29-32

Larsen JL (1988) A successful vaccination trial with a trivalent vaccine. Bull Eur Assoc Fish Pathol 8:82-84

Liu PV (1957) Survey of hemolysin production among species of Peudomonads. J Bacteriol 74:718-727

Loghothetis PN, Austin B (1994) Immune response of rainbow trout (Oncorhynchus mykiss, Walbaum) to Aeromonas hydrophila. Fish Shellfish Immunol 4:239-254

Magariños B, Romalde L, Santos Y, Casal JF, Barja JL, Toranzo AE (1994) Vaccination trials on gilthead seabream (Sparus aurata) against Pasteurella piscicida. Aquaculture 120:201-208

Magariños B, Romalde L, Barja JL, Núñez S, Toranzo AE (1999) Protection of gilthead seabream against Pasteurella piscicida at the larval stages. Bull Eur Assoc Fish Pathol 19: 159-161

Milton JS, Tsokos JO (1989) Estadística para Biología y Ciencias de la Salud. Interamericana McGraw-Hill, Spain

Muroga K, Jo Y, Nishibuchi M (1976a) Pathogenic Vibrio isolated from culture eels. I. Characteristics and taxonomic status. Fish Pathol 11:141-145

Muroga K, Jo Y, Nishibuchi M (1976b) Pathogenic Vibrio isolated from culture eels. I. Physiological characteristics and pathogenicity. Fish Pathol 11:147-151

Palm RC Jr, Landolt ML, Busch RA (1998) Route of vaccine administration: effects on the specific humoral response in rainbow trout Oncorhynchus mykiss. Dis Aquat Org 33: 157-166

Quentel C, Ogier de Baulny M (1995) Vaccination of juvenile turbot, Scophthalmus maximus L., against vibriosis. Aquaculture 132:125-131

Roberson BS (1990) Bacterial agglutination. In: Stolen JS, Fletcher TC, Anderson DP, Roberson BS, van Muiswinkel WB (eds) Techniques in fish immunology. SOS Publications, Fair Haven, NJ, p 81-86

Romalde JL, Silva R, Riaza A, Toranzo AE (1996) Long-lasting protection against turbot streptococcosis obtained with a toxoid-enriched bacterin. Bull Eur Assoc Fish Pathol 16: 169-171 
Rombout JWHM, Berg AA, van Berg CTGA, van de Witte P, Egberts E (1986) Immunization of carp (Cyprinus carpio) with Vibrio anguillarum bacterin: indications for a common mucosal immune system. Dev Comp Immunol 10: 341-351

Roogers WA, Xu D (1992) Protective immunity induced by a commercial Vibrio vaccine in hybrid striped bass. J Aquat Anim Health 4:303-305

Saeed MO, Plumb JA (1986) Immune response of channel catfish to lipopolysaccharide and whole cell Edwarsiella ictaluri vaccines. Dis Aquat Org 2:21-25

Salati F, Kusuda R (1985) Vaccine preparations used for immunization of eel Anguilla japonica against Edwarsiella tarda infection. Bull Jpn Soc Sci Fish 51:1233-1237

Santos Y, Bandín I, Núñez S, Gravningen $K$, Toranzo AE (1991) Protection of turbot, Scophthalmus maximus (L.), and rainbow trout, Oncorhynchus mykiss (Richardson), against vibriosis using two different vaccines. J Fish Dis 14:407-411

Smith PD (1988) Vaccination against vibriosis. In: Ellis AE (ed) Fish vaccination. Academic Press Ltd, London, p 67-84

Editorial responsibility: David Bruno, Aberdeen, Scotland, UK
Song YL, Kou GH (1981) The immuno-responses of eel (Anguilla japonica) against Edwarsiella anguillimortifera as studied by the immersion method. Fish Pathol 15:249-255

Song YL, Kou GH, Chen KY (1982) Vaccination conditions for the eel (Anguilla anguilla) with Edwarsiella anguillimortifera bacterin. CAPD Fisheries Ser 8:18-25

Tison DL, Nishibuchi M, Greenwood JD, Seidler RJ (1982) Vibrio vulnificus biogroup 2: new biogroup pathogenic for eels. Appl Environ Microbiol 44:640-646

Toranzo AE, Devesa S, Romalde JL, Lamas J, Riaza A, Leiro J, Barja JL (1995) Efficacy of intraperitoneal and immersion vaccination against Enterococcus sp. infection in turbot. Aquaculture 134:17-27

Velji MI, Albright LJ, Evelyn TPT (1990) Protective immunity in juvenile coho salmon Oncorhynchus kisutch following immunization with Vibrio ordalii lipopolysaccharide or from exposure to live $V$. ordalii cells. Dis Aquat Org 9:25-29

Westphal O, Jann K (1965) Bacterial lipopolysaccharides. Extraction with phenol-water and further applications of the procedures. In: Whistler L (ed) Methods in carbohydrate chemistry. Academic Press Inc, New York, p 83-91

Submitted: June 19, 2000; Accepted: September 7, 2000 Proofs received from author(s): October 20, 2000 